\title{
Effects of feeding lauric acid or coconut oil on ruminal protozoa numbers, fermentation pattern, digestion, omasal nutrient flow, and milk production in dairy cows ${ }^{1}$
}

\author{
A. P. Faciola ${ }^{* 2}$ and G. A. Broderick $†$ \\ *Department of Agriculture, Nutrition, and Veterinary Science, University of Nevada, Reno 89557 \\ †United States Dairy Forage Research Center, Agricultural Research Service, USDA, Madison, WI 53706
}

\begin{abstract}
The objectives of this study were to evaluate the feeding of coconut oil (CO), in which lauric acid (La) comprises about $50 \%$ of the fatty acid composition, as a practical rumen protozoa (RP) suppressing agent, to assess whether the source of La affects ruminal fermentation and animal performance and to test whether suppressing RP improves N utilization, nutrient digestion, nutrient flow at the omasal canal, and milk production. Fifteen multiparous Holstein cows (3 fitted with ruminal cannulas) and 15 primiparous Holstein cows (3 fitted with ruminal cannulas) were used in a replicated $3 \times 3$ Latin square experiment with $14 \mathrm{~d}$ of adaptation and $14 \mathrm{~d}$ of sample collection. Diets were fed as total mixed ration and contained (dry matter basis) $10 \%$ corn silage, $50 \%$ alfalfa silage, and $40 \%$ concentrate. The control diet contained 3\% (dry matter basis) calcium soaps of palm oil fatty acids (Megalac, Church \& Dwight Co. Inc., Princeton, NJ) as a ruminally inert fat source and had no added La or CO. Diets with La and $\mathrm{CO}$ were formulated to contain equal amounts of La (1.3\%, dry matter basis). Dry matter intake was not affected by treatment. Both CO and La reduced RP numbers by about $40 \%$. Lauric acid reduced yield of milk and milk components; however, $\mathrm{CO}$ did not affect yield of milk and yields of milk components. Both La and CO caused small reductions in total VFA concentration; CO increased molar proportion of ruminal propionate, reduced ruminal ammonia and branchedchain volatile fatty acids, suggesting reduced protein degradation, and reduced milk urea $\mathrm{N}$ and blood urea $\mathrm{N}$ concentrations, suggesting improved protein efficiency. Lauric acid reduced total-tract apparent digestibility of neutral detergent fiber and acid detergent fiber as
\end{abstract}

Received October 29, 2013.

Accepted May 5, 2014.

${ }^{1}$ Mention of any trademark or proprietary product in this paper does not constitute a guarantee or warranty of the product by the USDA or the Agricultural Research Service and does not imply its approval to the exclusion of other products that also may be suitable.

${ }^{2}$ Corresponding author: afaciola@cabnr.unr.edu well as ruminal apparent digestibility of neutral detergent fiber and acid detergent fiber as measured at the omasal canal; however, CO did not alter fiber digestion. Microbial protein flow at the omasal canal, as well as the flow of $\mathrm{N}$ fractions at the omasal canal, did not differ among treatments. Results from this experiment have confirmed that dietary La is not a practical agent for suppressing RP population in dairy cows, mainly because of its negative effects on fiber digestion and ruminal fermentation. Intake of $\mathrm{CO}$ appeared to reduce ruminal and improve protein efficiency, but did not improve milk production, milk composition, or increase microbial outflow from the rumen. Based on the results of this study, a $40 \%$ reduction of RP population is not sufficient to improve $\mathrm{N}$ utilization in dairy cows.

Key words: coconut oil, dairy cow, protozoa

\section{INTRODUCTION}

Protein is an expensive dietary nutrient; furthermore, excessive excreted $\mathrm{N}$ is an important environmental concern. Therefore, improving $\mathrm{N}$ utilization is a major challenge in ruminant nutrition research. The main sources of AA for ruminant animals are the microbial protein synthesized in the rumen and RUP; however, according to Jouany (1996), ruminal protozoa (RP) have a negative effect on protein utilization in ruminants because they reduce ruminal outflow of both microbial protein and RUP. Moreover, RP are the main contributors to bacterial protein turnover in the rumen (Wallace and McPherson, 1987), which is a consequence of RP predation on bacteria. Rumen protozoa possess protease (Forsberg et al., 1984), peptidase (Newbold et al., 1989), and deaminase (Itabashi and Kandatsu, 1975) activity; therefore, they actively degrade proteins, peptides, and AA, producing large amounts of ruminal ammonia, which they cannot completely use, therefore contributing to urinary urea excretion.

Medium-chain FA, such as lauric acid (La; C12:0), have been shown to have potent antiprotozoal effects (Newbold and Chamberlain, 1988; Hristov et al., 2011; Faciola and Broderick, 2013). Furthermore, they may 
be used routinely in farm operations and may have the potential to replace hazardous antiprotozoal chemicals.

Although suppression of RP may have the potential to improve $\mathrm{N}$ utilization in the rumen, achieving the level of RP suppression that would allow such improvement is still a challenge. Faciola et al. (2013) observed a strong antiruminal protozoa activity of La when a single dose of $160 \mathrm{~g} / \mathrm{d}$ was given via ruminal cannula, reducing RP by $90 \%$ within $2 \mathrm{~d}$ of treatment. However, when La was fed at 160 and $240 \mathrm{~g} / \mathrm{d}$ in the TMR, RP were reduced by only 25 and $30 \%$, respectively, showing that these amounts mixed in the diet were not sufficient to suppress RP effectively. In a subsequent study, Faciola and Broderick (2013) tested greater doses of La in the $\operatorname{TMR}(240,480$, and $720 \mathrm{~g} / \mathrm{d})$, aiming to determine the dietary amount of La that would effectively suppress RP. These amounts reduced RP by 28,50 , and $64 \%$, respectively; however, the 2 highest amounts also drastically reduced DMI and impaired ruminal fermentation and, consequently, decreased milk production. It has been speculated that high doses of La may affect diet palatability (Hristov et al., 2011). Coconut oil (CO), in which La comprises about $50 \%$ of the FA composition, may be an alternative to feeding La because it may not have the same negative effects on DMI and ruminal fermentation (Faciola and Broderick, 2013). Therefore, the main goal of the present study was to evaluate dietary $\mathrm{CO}$ as a practical RP-suppressing agent and to test whether suppressing RP improves $\mathrm{N}$ utilization, nutrient digestibility, nutrient flow at the omasal canal, as well as milk composition and production. We hypothesized that $\mathrm{CO}$ would suppress RP numbers without depressing DMI and ruminal fermentation, thereby improving $\mathrm{N}$ utilization and milk production.

\section{MATERIALS AND METHODS}

Care and handling of all experimental animals, including ruminal cannulation, were conducted under protocols approved by the University of Wisconsin Institutional Animal Care and Use Committee. Fifteen multiparous Holstein cows (3 fitted with permanent ruminal cannulas), averaging $2.5 \pm 0.9$ parity, $71 \pm 39$ DIM, $39.8 \pm 3.7 \mathrm{~kg} / \mathrm{d}$ of milk, and $621 \pm 60 \mathrm{~kg} \mathrm{BW}$, and 15 primiparous Holstein cows (3 fitted with permanent ruminal cannulas), averaging $123 \pm 53$ DIM, 36.3 $\pm 4 \mathrm{~kg} / \mathrm{d}$ of milk, and $545 \pm 62 \mathrm{~kg} \mathrm{BW}$ at the beginning of the study, were blocked by parity and by DIM within parity into 10 squares of 3 cows (2 squares of cannulated cows). Cows were randomly assigned within squares to 3 balanced dietary treatment sequences [i.e., with each diet following every other diet twice in each pair (multiparous and primiparous) of squares over the trial] in a replicated $3 \times 3$ Latin square with $14 \mathrm{~d}$ of adaptation and $14 \mathrm{~d}$ of sampling.

Composition of the fermented feeds fed is in Table 1. Diets were fed as a TMR and contained (DM basis) $10 \%$ corn silage, $50 \%$ alfalfa silage, and $40 \%$ concentrate (Table 2). The control diet contained calcium soaps of palm oil FA (Megalac, Church \& Dwight Co. Inc./Arm \& Hammer Animal Nutrition, Princeton, NJ) as a ruminally inert fat source with no added La $(99 \%$ La, KIC Chemicals Inc., Armonk, NY) or CO (Columbus Food Inc., Chicago, IL). The calcium soaps of palm oil FA, La, and CO were first thoroughly mixed with ground shelled corn and then mixed with the other concentrate ingredients before being mixed with the forages and fed as TMR. Both control and $\mathrm{CO}$ diets had the same ether extract content. Diets La and CO were formulated to contain equal amounts of $\mathrm{La}(1.3 \%$ on a DM basis), either as La (diet La) or in the form of coconut oil (diet CO).

All cows were injected every other week with bovine somatotropin (500 mg of Posilac, Elanco Animal Health, Greenfield, IN) from about 60 DIM; injections were synchronized such that animals received a full dose on d 1 and at 14-d intervals throughout the trial. Cows were housed in tiestalls and had free access to water during the trial.

Diets were offered once daily at $1000 \mathrm{~h}$. Orts were collected and weights recorded at $0900 \mathrm{~h}$ and feeding rate was adjusted daily to yield orts of about 5 to $10 \%$ of intake. Weekly composites of corn silage, alfalfa silage, high-moisture shelled corn, TMR, and orts were taken from daily samples of about $0.5 \mathrm{~kg}$ that were stored at $-20^{\circ} \mathrm{C}$. Weekly samples were also taken of ground corn grain and solvent-extracted soybean meal and stored at room temperature. The DM was determined in weekly composites of corn silage, alfalfa silage, and rolled highmoisture shelled corn by drying at $60^{\circ} \mathrm{C}$ for $48 \mathrm{~h}$ and in weekly samples of ground corn grain and solventextracted soybean meal at $105^{\circ} \mathrm{C}$, according to AOAC (1980). Weekly samples of feed ingredients were also analyzed for total $\mathrm{N}$ using a combustion assay (Leco FP-2000 N Analyzer, Leco Instruments Inc., St. Joseph, MI). Ingredient DM and $\mathrm{N}$ contents were used to adjust dietary composition weekly to maintain constant DM proportions from each feed ingredient and equal $\mathrm{CP}$ contents in each diet. Intake of DM was computed based on the $60^{\circ} \mathrm{C}$ DM determinations for TMR and orts. After drying, ingredients and TMR were ground through a 1-mm screen (Wiley mill, Arthur H. Thomas, Philadelphia, PA). Samples were analyzed for total N (Leco FP-2000 N Analyzer, Leco Instruments Inc., St. Joseph, MI); DM at $105^{\circ} \mathrm{C}$; ash and $\mathrm{OM}$ by $\mathrm{AOAC}$ (1980) methods; sequentially for NDF and ADF; and 
Table 1. Chemical composition of fermented feeds

\begin{tabular}{lrrc}
\hline Item & $\begin{array}{c}\text { Alfalfa } \\
\text { silage }\end{array}$ & $\begin{array}{c}\text { Corn } \\
\text { silage }\end{array}$ & $\begin{array}{c}\text { High-moisture } \\
\text { shelled corn }\end{array}$ \\
\hline DM, \% & 38.4 & 37.5 & 73.5 \\
CP, \% DM & 21.5 & 6.9 & 7.3 \\
NDF, \% DM & 37.7 & 42.3 & 8.4 \\
ADF, \% DM & 28.5 & 21.1 & 2.3 \\
Ash, \% DM & 11.1 & 4.0 & 1.9 \\
NDIN, \% total N & 7.1 & 5.8 & 7.0 \\
ADIN, \% total N & 3.2 & 1.1 & 3.9 \\
NPN, \% total N & 62.2 & 60.0 & 49.5 \\
Free AA-N, \% total NPN & 33.1 & 32.5 & 23.2 \\
Ammonia N, \% total NPN & 6.5 & 8.8 & 3.7 \\
Unidentified N ${ }^{2}$ of total NPN & 22.6 & 18.7 & 22.6 \\
pH & 4.7 & 4.2 & 4.4 \\
\hline
\end{tabular}

${ }^{1}$ Computed based on a mean $40.3 \mu \mathrm{mol}$ of total free $\mathrm{AA} / \mathrm{mg}$ of $\mathrm{N}$ in alfalfa and corn silage.

${ }^{2}$ Unidentified $\mathrm{N}$ = total $\mathrm{N}$ - Free AA-N - Ammonia-N (Broderick, 1987).

Table 2. Composition of diets

\begin{tabular}{|c|c|c|c|}
\hline Item & Control & Lauric acid & Coconut oil \\
\hline \multicolumn{4}{|l|}{ Ingredient, \% DM } \\
\hline Alfalfa silage & 50.0 & 50.0 & 50.0 \\
\hline Corn silage & 10.0 & 10.0 & 10.0 \\
\hline High-moisture shelled corn & 16.8 & 18.8 & 16.8 \\
\hline Dry molasses & 9.9 & 9.9 & 9.9 \\
\hline Solvent soybean meal & 4.6 & 4.3 & 4.6 \\
\hline Ground shelled corn & 4.1 & 4.1 & 4.1 \\
\hline Calcium soaps of palm oil $\mathrm{FA}^{1}$ & 3.0 & 0.0 & 0.0 \\
\hline Lauric acid & 0.0 & 1.3 & 0.0 \\
\hline Coconut oil & 0.0 & 0.0 & 3.0 \\
\hline Sodium bicarbonate & 0.75 & 0.75 & 0.75 \\
\hline Limestone & 0.36 & 0.36 & 0.36 \\
\hline Dicalcium phosphate & 0.24 & 0.24 & 0.24 \\
\hline Salt & 0.16 & 0.16 & 0.16 \\
\hline Vitamin-mineral premix ${ }^{2}$ & 0.08 & 0.08 & 0.08 \\
\hline \multicolumn{4}{|l|}{ Composition } \\
\hline DM, \% & 49.2 & 48.9 & 49.4 \\
\hline $\mathrm{OM}, \%$ of $\mathrm{DM}$ & 92.9 & 92.8 & 92.9 \\
\hline $\mathrm{NDF}, \%$ of DM & 28.4 & 28.7 & 28.4 \\
\hline $\mathrm{ADF}, \%$ of $\mathrm{DM}$ & 18.4 & 18.4 & 18.4 \\
\hline $\mathrm{CP}, \%$ of DM & 16.1 & 16.2 & 16.1 \\
\hline $\mathrm{RDP}^{3} \%$ of DM & 10.4 & 10.5 & 10.4 \\
\hline $\mathrm{RUP}^{3} \%$ of DM & 5.1 & 5.0 & 5.1 \\
\hline Ether extract, \% of DM & 6.9 & 5.5 & 6.9 \\
\hline $\mathrm{Ca},{ }^{3} \%$ of DM & 1.35 & 1.06 & 1.06 \\
\hline $\mathrm{P}^{3} \%$ of DM & 0.37 & 0.37 & 0.37 \\
\hline $\mathrm{NFC}^{4}$ & 39.2 & 40.2 & 39.2 \\
\hline $\mathrm{NE}_{\mathrm{L}}{ }^{5} \mathrm{Mcal} / \mathrm{kg}$ of $\mathrm{DM}$ & 1.65 & 1.64 & 1.65 \\
\hline NDIN, $\%$ of total $\mathrm{N}$ & 6.30 & 6.32 & 6.30 \\
\hline ADIN, $\%$ of total $\mathrm{N}$ & 2.58 & 2.59 & 2.58 \\
\hline Fraction $\mathrm{B} 3,{ }^{6} \%$ of total $\mathrm{N}$ & 3.72 & 3.73 & 3.72 \\
\hline NPN ${ }^{7} \%$ of total $\mathrm{N}$ & 20.1 & 20.1 & 20.1 \\
\hline
\end{tabular}

${ }^{1}$ Megalac; Church \& Dwight Co. Inc., Princeton, NJ. Contained $85 \%$ fat.

${ }^{2}$ Provided (per kilogram of DM): $56 \mathrm{mg}$ of $\mathrm{Zn}$ as zinc oxide, $46 \mathrm{mg}$ of $\mathrm{Mn}$ as manganous oxide, $22 \mathrm{mg}$ of $\mathrm{Fe}$ as ferrous sulfate, $12 \mathrm{mg}$ of $\mathrm{Cu}$ as copper sulfate, $0.9 \mathrm{mg}$ of I as potassium iodide, $0.4 \mathrm{mg}$ of Co as cobalt oxide, $0.3 \mathrm{mg}$ of Se as sodium selenite, 6,440 IU of vitamin A, 2,000 IU of vitamin D, and 16 IU of vitamin E.

${ }^{3}$ Predicted from the NRC (2001) model.

${ }^{4} \mathrm{NFC}=100-(\% \mathrm{NDF}+\% \mathrm{CP}+\%$ fat $+\%$ ash $)+\%$ NDIN $\times 6.25$, according to NRC (2001) model and using fat contents of individual dietary ingredients from NRC (2001) tables.

${ }^{5}$ Computed by discounting dietary energy based on actual DMI (NRC, 2001).

${ }^{6}$ Fraction B3 (Fox et al., 2004) = NDIN (\% of total N) - ADIN (\% of total N).

${ }^{7}$ Proportion of total N soluble in $10 \%$ (wt/vol) TCA (Muck, 1987). 
using a heat-stable $\alpha$-amylase and $\mathrm{Na}_{2} \mathrm{SO}_{3}$ (Van Soest et al., 1991; Hintz et al., 1996) for indigestible ADF (ADF remaining after a 12-d in situ incubation; Huhtanen et al., 1994), NDIN and ADIN ( $\mathrm{N}$ fraction in NDF and ADF residue, respectively), and ether extract (AOAC, 1990). Composite samples of TMR were also analyzed for NPN (Muck, 1987; Leco FP-2000 N Analyzer; Leco Instruments Inc.). Orts and TMR were analyzed for La as described by Sukhija and Palmquist (1988). For computation of BW change, BW was measured on 3 consecutive days at the beginning of the experiment and at the end of each period.

On d 21 of each period, about 100 to $200 \mathrm{~mL}$ of digesta was collected from 4 locations in the ventral rumen at 0 (just before feeding), 1, 2, 4, 8, 12, 18, and 24 $\mathrm{h}$ after feeding, strained through 2 layers of cheesecloth, and $\mathrm{pH}$ was measured immediately using a glass electrode. A daily composite of strained ruminal fluid was prepared for each cow at each treatment and RP counts were determined in duplicate as described by Dehority (1993). Two 10-mL samples of composite ruminal fluid were then preserved in scintillation vials by addition of $0.2 \mathrm{~mL}$ of $50 \% \mathrm{H}_{2} \mathrm{SO}_{4}$ and stored at $-20^{\circ} \mathrm{C}$. Just before analysis, samples were thawed and centrifuged $\left(15,300 \times g\right.$ for $20 \mathrm{~min}$ at $\left.4^{\circ} \mathrm{C}\right)$ and flow-injection analyses (Lachat Quik-Chem 8000 FIA; Lachat Instruments, Milwaukee, WI) were applied to supernatants to determine ammonia, using a phenol-hypochlorite method (Lachat Method 18-107-06-1-A; Lachat), and total AA, using a fluorimetric procedure based on the reaction with o-phthaldialdehyde (Roth, 1971). Leucine was the standard in the $o$-phthaldialdehyde assay and total AA are reported in Leu equivalents. Samples were also thawed and centrifuged $\left(28,000 \times g\right.$ for $30 \mathrm{~min}$ at $\left.4^{\circ} \mathrm{C}\right)$ for determination of individual and total ruminal VFA using a modification of the gas-liquid chromatography method for free FA as described by Brotz and Schaefer (1987). This method does not resolve isovalerate and 2-methylbutyrate, which are reported as isovalerate plus 2-methylbutyrate.

Omasal sampling was performed on the rumen cannulated cows during the last week of each period using the techniques developed by Huhtanen et al. (1997) and Ahvenjärvi et al. (2000), as adapted by Reynal and Broderick (2005), to quantify digesta flow out of the rumen. Indigestible NDF (Huhtanen et al., 1994), $\mathrm{YbCl}_{3}$ (Siddons et al., 1985), and Co-EDTA (Udén et al., 1980), which are mainly associated with, respectively, the large particle, small particle, and fluid phases of digesta, were used as flow markers at the omasal canal. Indigestible NDF was determined in large particles, small particles, and TMR (but not in fluid phases; Ahvenjärvi et al., 2000). Samples (0.35 g) were weighted into duplicate $5 \times 10-\mathrm{cm}$ Dacron bags
(Sericol, Broadstairs, UK) with a $6-\mu \mathrm{m}$ pore size, incubated in the rumens of 2 cows for $12 \mathrm{~d}$, rinsed with water, then subjected to NDF analysis as previously described. The external microbial marker, ${ }^{15} \mathrm{~N}$, was used to quantify microbial NAN flow from the rumen. The triple marker technique of France and Siddons (1986) was used to determine the proportions with which to recombine the 3 phases to produce omasal true digesta. Before marker infusion began, whole ruminal contents were taken from each cow to determine the background ${ }^{15} \mathrm{~N}$ abundance. Cobalt-EDTA, $\mathrm{YbCl}_{3}$, and ${ }^{15} \mathrm{NH}_{4} \mathrm{SO}_{4}$ containing $10 \%$ atom excess ${ }^{15} \mathrm{~N}$ (Isotec, Miamisburg, $\mathrm{OH})$ were dissolved in distilled water and continuously infused into the rumen at rates of $2.01 \mathrm{~g}$ of Co, $2.88 \mathrm{~g}$ of $\mathrm{Yb}$, and $210 \mathrm{mg}$ of ${ }^{15} \mathrm{~N}$ per day in $2.62 \mathrm{~L} / \mathrm{d}$ of solution. Markers were continuously infused for $158 \mathrm{~h}$ from 0800 h on d 20 to $2200 \mathrm{~h}$ on d 26 using a peristaltic pump (AutoAnalyzer II, Technicon Corp., St. Louis, MO). After $86 \mathrm{~h}$ of infusion, omasal samples were collected at twelve 2-h intervals over a 3 -d period to represent the 24-h day. Sampling protocols, including confirming that sample tubes were correctly positioned in the omasal canal, sampling times and volumes, sample processing, isolation of fluid- and particle-associated bacteria, digesta marker analyses, and preparation of omasal true digesta were as described by Reynal and Broderick (2005) and Brito et al. (2007), except that ammonia and protozoa were not isolated for determination of ${ }^{15} \mathrm{~N}$ enrichment. Samples of omasal true digesta were analyzed for total $\mathrm{N}, \mathrm{DM}\left(105^{\circ} \mathrm{C}\right)$, ash, OM, NDF, ADF, NDIN, and ADIN as detailed previously for feed samples. Samples of omasal true digesta and isolated bacteria were treated with $\mathrm{K}_{2} \mathrm{CO}_{3}$ (Brito et al., 2007) to remove residual ammonia and analyzed for total $\mathrm{N}$ (equivalent to NAN) and for ${ }^{15} \mathrm{~N}$ abundance using a Costech 4010 elemental analyzer (Costech Analytical Technologies Inc., Valencia, CA) interfaced to a Thermo-Finnigan Delta-Plus Advantage isotope ratio mass spectrometer (Thermo-Electron GmbH, Bremen, Germany). Equations used to compute flows of nutrients of dietary and microbial origin and extents of ruminal digestion were those detailed by Brito et al. (2007).

Cows were milked twice daily at 0600 and $1700 \mathrm{~h}$ and milk yield was recorded at each milking in all experimental periods. Milk samples from morning and afternoon milkings were collected on d 18 and 25 of each period and analyzed for fat, true protein, lactose, and SNF by infrared analysis (AgSource, Verona, WI) with a spectrum analyzer (FT6000; Foss North America Inc., Eden Prairie, MN) using AOAC (1990) method 972.16. For MUN determination, $5 \mathrm{~mL}$ of milk from all milking samples were treated with $5 \mathrm{~mL}$ of $25 \%$ (wt/vol) TCA. Samples were vortexed and allowed to stand for $30 \mathrm{~min}$ at room temperature before filtering through Whatman 
No. 1 filter paper (Whatman Inc., Piscataway, NJ). Filtrates were stored at $-20^{\circ} \mathrm{C}$ until MUN analysis by an automated colorimetric assay (Broderick and Clayton, 1997) adapted to flow injection (Lachat Quik-Chem 8000 FIA; Lachat Instruments). Concentrations and yields of fat, true protein, and lactose, as well as SNF and MUN concentration were calculated as weighted means from morning and afternoon milk yields on each test day. Yield of 3.5\% FCM was calculated according to Sklan et al. (1992).

Efficiency of conversion of feed DM was calculated for each cow over the last 2 wk of each period by dividing mean yield of actual milk and FCM by mean DMI. Efficiency of utilization of feed $\mathrm{N}$ was calculated for each cow by dividing mean milk $\mathrm{N}$ output (milk true protein/6.38) by mean $\mathrm{N}$ intake, assuming no net deposit or mobilization of $\mathrm{N}$ from body tissues.

On d 26 and 27 of each period, 2 spot urine and 2 spot fecal samples were collected from all 28 cows at 6 and $18 \mathrm{~h}$ after feeding. Fecal samples were dried in a forced-draft oven $\left(60^{\circ} \mathrm{C} ; 72 \mathrm{~h}\right)$ and then ground through a 1-mm screen (Wiley mill). Equal DM from each fecal subsample was mixed to obtain 1 composite sample for each cow in each period. Fecal samples were analyzed for total DM, ash, OM, N, NDF, ADF, and indigestible $\mathrm{ADF}$ as described earlier. Indigestible ADF was used as an internal marker to estimate both apparent total tract nutrient digestibility and fecal output (Cochran et al., 1986). Urine samples were acidified immediately after collection by diluting 1 volume of urine with 4 volumes of $0.072 \mathrm{~N} \mathrm{H}_{2} \mathrm{SO}_{4}$ and stored at $-20^{\circ} \mathrm{C}$. Later, urine samples were thawed at room temperature and filtered through Whatman No. 1 filter paper. Filtrates were analyzed for creatinine using a picric acid method (Oser, 1965) adapted to flow-injection analysis (Lachat Quik-Chem 8000 FIA; Lachat Instruments), for total $\mathrm{N}$ using a N analyzer (Leco FP-2000 N Analyzer; Leco Instruments Inc.), for allantoin using the method of Vogels and van der Grift (1970) adapted to a 96-well plate reader, for uric acid using a commercial kit (No. 683-100P, Sigma Chemical Co., St. Louis, MO), and for urea with the colorimetric method also used for MUN. Daily urine volume was calculated based on individual BW and using a creatinine excretion rate of $29 \mathrm{mg} / \mathrm{kg}$ of BW (Valadares et al., 1999). Urinary urea $\mathrm{N}$, total $\mathrm{N}$, and purine derivatives (allantoin plus uric acid) were calculated based on their individual daily excretion multiplied by daily urine volume.

Blood samples were taken into heparinized tubes $4 \mathrm{~h}$ after feeding from the coccygeal artery or vein of each cow on $\mathrm{d} 26$ of each period and stored at $-20^{\circ} \mathrm{C}$ until analyzed. After thawing at room temperature, $5 \mathrm{~mL}$ of blood were transferred to a $15-\mathrm{mL}$ centrifuge tube, 1.25 $\mathrm{mL}$ of $25 \%$ TCA (wt/vol) was added, and tubes were vortexed, held for $30 \mathrm{~min}$ at room temperature, centrifuged $\left(15,000 \times g, 15 \mathrm{~min}, 4^{\circ} \mathrm{C}\right)$, and the supernatants were stored at $-20^{\circ} \mathrm{C}$ until analyzed for BUN with the flow injection system used for MUN.

Results were analyzed using the MIXED procedures of SAS (SAS Institute Inc., Cary NC). No parity effects were observed; therefore, parity was removed from the model. The following model was used to fit the data to assess effects of dietary treatments:

$$
\mathrm{Y}_{i j k l}=\mu+\mathrm{S}_{i}+\mathrm{P}_{j}+\mathrm{C}_{k(i)}+\mathrm{T}_{l}+\mathrm{ST}_{i l}+e_{i j k l},
$$

where $\mathrm{Y}_{i j k l}=$ dependent variable; $\mu=$ overall mean; $\mathrm{S}_{i}$ $=$ effect of square $i ; \mathrm{P}_{j}=$ effect of period $j ; \mathrm{C}_{k(i)}=$ effect of cow $k$ (within square $i$ ); $\mathrm{T}_{l}=$ effect of treatment $l$; $\mathrm{ST}_{i l}=$ interaction between square $i$ and treatment $l$; and $e_{i j k l}=$ residual error. All terms were considered fixed, except for $\mathrm{C}_{k(i)}$ and $e_{i j k l}$, which were considered random. The following model was used for ruminal variables, for which repeated measurements over time were used ( $\mathrm{pH}$, ammonia, total free AA, RP number, and individual and total VFA):

$$
\begin{aligned}
\mathrm{Y}_{i j k l m} & =\mu+\mathrm{S}_{i}+\mathrm{P}_{j}+\mathrm{C}_{k(i)}+\mathrm{T}_{l}+\mathrm{ST}_{i l} \\
& +\mathrm{E}_{i j k l}+\mathrm{Z}_{m}+\mathrm{ZT}_{m l}+\omega_{i j k l m},
\end{aligned}
$$

where $\mathrm{Y}_{i j k l m}=$ dependent variable; $\mu=$ overall mean; $\mathrm{S}_{i}=$ effect of square $i ; \mathrm{P}_{j}=$ effect of period $j ; \mathrm{C}_{k(i)}=$ effect of cow $k$ (within square $i$ ); $\mathrm{T}_{l}=$ effect of treatment $l ; \mathrm{ST}_{i l}=$ interaction between square $i$ and treatment $l ; \mathrm{E}_{i j k l}=$ whole plot error; $\mathrm{Z}_{m}=$ effect of time $m$; $\mathrm{ZT}_{m l}=$ interaction between time $m$ and treatment $l$; and $\omega_{i j k l m}=$ subplot error. Repeated measures analyses were performed using the $\mathrm{SP}(\mathrm{POW})$ structure of SAS. All terms were considered fixed, except for $\mathrm{C}_{k(i)}$, $\mathrm{E}_{i j k l}$, and $\omega_{i j k l m}$, which were considered random. For all models used, the interaction term $\mathrm{ST}_{i l}$ or $\mathrm{ST}_{i m}$ was removed when $P>0.25$. Original RP data was tested in SAS for homogeneity of variance and normality; moreover, RP residuals were tested for normality. Log-transformed RP data only marginally improved normality; therefore, analysis was done using original data. The Tukey-Kramer method was used to adjust for multiple comparisons and to perform mean separations (SAS). For all analyses, significance was declared at $P \leq 0.05$.

\section{RESULTS AND DISCUSSION}

In the current study, no differences in DMI $(P=$ 0.18 ) were observed among treatments (Table 3). Effects of La on DMI have been conflicting. Faciola et 
al. (2013) did not observe a reduction in DMI when a single dose of $160 \mathrm{~g} / \mathrm{d}$ of La was added directly into the rumen just before feeding in a preliminary trial $(\mathrm{n}=6)$ or when up to $243 \mathrm{~g} / \mathrm{d}$ of La was mixed in the TMR of dairy cows in a larger study $(\mathrm{n}=52)$. Moreover, Faciola and Broderick (2013) observed no reduction in DMI when dairy cows consumed $438 \mathrm{~g} / \mathrm{d}$ of La in 1 trial; however, in subsequent studies, these authors detected reduced DMI when $220 \mathrm{~g} / \mathrm{d}$ of La and 404 and $543 \mathrm{~g} / \mathrm{d}$ of La were fed in the TMR. Others have also observed variable DMI responses to feeding La; Hristov et al. (2009) did not observe reduced DMI when $240 \mathrm{~g} / \mathrm{d}$ of La was dosed into the rumen of dairy cows before feeding. However, Hristov et al. (2011) later found that DMI was reduced $26 \%$ when $240 \mathrm{~g} / \mathrm{d}$ of La was dosed into the rumen of dairy cows before feeding (26.9 vs. $20.0 \mathrm{~kg} / \mathrm{d}$ with control and La, respectively). Delivery method, La concentration in the diet, La dosage, and basal diet characteristics all appear to play important roles in the DMI response to La. Hristov et al. (2011) speculated that La may have low palatability and that this may be an issue in its practical usage for suppressing RP. Effects of $\mathrm{CO}$ on DMI have also been conflicting. Hristov et al. (2009) saw no reduction in DMI when $240 \mathrm{~g} / \mathrm{d}$ of $\mathrm{CO}$ was dosed into the rumen of dairy cows before feeding. However, Lee et al. (2011) observed reduced DMI when $500 \mathrm{~g} / \mathrm{d}$ of $\mathrm{CO}$ was consumed by dairy cows. However, Jordan et al. (2006) did not find reduced DMI when 41 beef heifers were fed $250 \mathrm{~g} / \mathrm{d}$ of CO. More recently, Reveneau et al. (2012) reported a $4.2 \mathrm{~kg} / \mathrm{d}$ reduction in DMI when $5 \% \mathrm{CO}$ was added to the diets of 6 lactating dairy cows. Hollmann and Beede (2012) also reported reductions in DMI when CO replaced mainly ground corn in the diets of lactating dairy cows, which increased the ether extract content of the CO diet compared with the control (10.4 vs. $5.7 \%$, respectively). Moreover, these authors stated that the high starch levels fed in their diets $(30.1 \%$, DM basis) may have led to higher propionate availability, which may have exacerbated the DMI depression observed when $\mathrm{CO}$ was fed. The negative effects of $\mathrm{CO}$ on DMI reported when CO replaces dietary carbohydrates may be a consequence of higher fat concentration in the diet. Replacing carbohydrates with fats has been associated with DMI depression (Onetti et al., 2003) and some of the possible explanations for this depression in DMI may be related to decreased NDF digestion, oxidation of metabolic fuels, gut peptide responses, and palatability, as explained by Hollmann and Beede (2012).

Dosing La straight into the rumen via rumen cannula theoretically eliminates palatability issues, which may partially explain why some studies did not detect reductions in DMI when dosing La or CO (Hristov et al., 2009; Faciola et al., 2013). Caution should be used when comparing doses among experiments because different amounts of DMI may dilute or concentrate the amount of La or CO actually reaching the rumen. Other important issues include concentrations of total fat, starch, and fiber in the basal diet, all of which may influence DMI response relative to La and CO inclusion (Hristov et al., 2011; Faciola and Broderick, 2013). In

Table 3. Effects of feeding lauric acid (La) or coconut oil (CO) on DMI, milk production and composition, and blood urea concentration ${ }^{1}$

\begin{tabular}{|c|c|c|c|c|c|}
\hline \multirow[b]{2}{*}{ Item } & \multicolumn{3}{|c|}{ Diet } & \multirow[b]{2}{*}{ SEM } & \multirow[b]{2}{*}{$P$-value } \\
\hline & Control & $\mathrm{La}$ & $\mathrm{CO}$ & & \\
\hline La intake, $\mathrm{g} / \mathrm{d}$ & 0 & 288 & 275 & - & - \\
\hline DMI, kg/d & 22.5 & 22.2 & 22.9 & 0.6 & 0.18 \\
\hline Milk yield, kg/d & $35.6^{\mathrm{a}}$ & $34.1^{\mathrm{b}}$ & $35.9^{\mathrm{a}}$ & 1.7 & $<0.01$ \\
\hline $3.5 \% \mathrm{FCM}^{2}{ }^{2} \mathrm{~kg} / \mathrm{d}$ & $39.5^{\mathrm{a}}$ & $36.1^{\mathrm{b}}$ & $38.6^{\mathrm{a}}$ & 1.3 & $<0.01$ \\
\hline $3.5 \% \mathrm{FCM} / \mathrm{DMI}$ & $1.75^{\mathrm{a}}$ & $1.62^{\mathrm{c}}$ & $1.68^{\mathrm{b}}$ & 0.04 & 0.02 \\
\hline Milk N/N intake, $\%$ & $28.7^{\mathrm{a}}$ & $28.1^{\mathrm{b}}$ & $28.7^{\mathrm{a}}$ & 0.4 & 0.03 \\
\hline Fat, $\%$ & $4.19^{\mathrm{a}}$ & $3.95^{\mathrm{b}}$ & $4.05^{\mathrm{ab}}$ & 0.14 & 0.05 \\
\hline Fat yield, $\mathrm{kg} / \mathrm{d}$ & $1.49^{\mathrm{a}}$ & $1.32^{\mathrm{b}}$ & $1.42^{\mathrm{a}}$ & 0.07 & $<0.01$ \\
\hline True protein, $\%$ & 2.98 & 3.03 & 3.01 & 0.07 & 0.32 \\
\hline True protein yield, $\mathrm{kg} / \mathrm{d}$ & $1.06^{\mathrm{a}}$ & $1.03^{\mathrm{b}}$ & $1.08^{\mathrm{a}}$ & 0.03 & 0.03 \\
\hline Lactose, \% & $4.93^{\mathrm{a}}$ & $4.82^{\mathrm{b}}$ & $4.77^{\mathrm{c}}$ & 0.05 & 0.05 \\
\hline Lactose yield, $\mathrm{kg} / \mathrm{d}$ & $1.75^{\mathrm{a}}$ & $1.64^{\mathrm{b}}$ & $1.71^{\mathrm{a}}$ & 0.07 & $<0.01$ \\
\hline SNF, $\%$ & $8.81^{\mathrm{a}}$ & $8.76^{\mathrm{ab}}$ & $8.69^{b}$ & 0.11 & 0.05 \\
\hline SNF yield, $\mathrm{kg} / \mathrm{d}$ & $3.14^{\mathrm{a}}$ & $3.00^{\mathrm{b}}$ & $3.12^{\mathrm{a}}$ & 0.11 & $<0.01$ \\
\hline MUN, mg/dL & $11.3^{\mathrm{a}}$ & $11.1^{\mathrm{a}}$ & $10.4^{\mathrm{b}}$ & 0.40 & $<0.01$ \\
\hline $\mathrm{BUN}, \mathrm{mg} / \mathrm{dL}$ & $13.5^{\mathrm{a}}$ & $13.2^{\mathrm{a}}$ & $12.2^{\mathrm{b}}$ & 0.42 & $<0.01$ \\
\hline BW change, $\mathrm{kg} / \mathrm{d}$ & +0.04 & +0.07 & +0.02 & 0.18 & 0.34 \\
\hline
\end{tabular}


the present study, the feeding about $10 \%$ dry molasses (DM basis) may have helped to alleviate some of the negative effects of La and CO on DMI (Broderick and Radloff, 2004); therefore, potential palatability problems may have been minimized. Moreover, the La and $\mathrm{CO}$ diets were balanced to contain equal amounts of $\mathrm{La}$, and control and $\mathrm{CO}$ diets were balanced to contain the same amounts of total fat. This design likely reduced the chances of detecting differences in DMI. Discrepancies in DMI among earlier studies may have arisen from replacing carbohydrates with $\mathrm{La}$ and $\mathrm{CO}$ or from feeding diets with different fat contents (Hollmann and Beede, 2012).

Milk and $3.5 \%$ FCM yields were reduced $(P<0.01)$ when La, but not CO, was fed (Table 3). Compared with the control treatment, La reduced efficiency of milk production, expressed as FCM/DMI $(P=0.02)$, and efficiency of dietary $\mathrm{N}$ utilization, expressed by milk $\mathrm{N} / \mathrm{N}$ intake $(P=0.03)$. Lauric acid also reduced (Table $3)$ yields of fat $(P<0.01)$, protein $(P=0.03)$, lactose $(P<0.01)$, SNF $(P<0.01)$, as well as milk fat percentage $(P=0.05)$, which may be related to depressed fiber digestion, which will be discussed in more detail herein. Coconut oil reduced FCM/DMI $(P=0.02)$ and concentrations of lactose and $\operatorname{SNF}(P=0.05)$ (Table $3)$. Reductions in yield of milk and milk components were reported previously when La was directly dosed into the rumen (Hristov et al., 2011) and when mixed into the TMR of lactating cows (Faciola and Broderick, 2013); in both studies, DMI depression likely played a role in reducing milk production. Milk yield was not affected in studies in which DMI was not reduced by La (Hristov et al., 2009; Faciola et al., 2013). Hristov et al. (2009) did not observe decreased milk yield when $530 \mathrm{~g} / \mathrm{d}$ of $\mathrm{CO}$ was dosed into the rumen before feeding; however, Lee et al. (2011) reported decreased yield of milk and milk components when $500 \mathrm{~g} / \mathrm{d}$ of $\mathrm{CO}$ was fed to dairy cows. Moreover, Storry et al. (1974) reported depressed yield of milk and milk components when CO was mixed with the concentrate at rates of 10 and $15 \%$ (CO intakes ranging from 730 to 1,245 g/d). Reveneau et al. (2012) and Hollmann and Beede (2012) also observed reductions in milk yield when $\mathrm{CO}$ was added to the diets of lactating dairy cows and reduced DMI was reported to be the primary reason why milk production was decreased.

Typically, reduced BUN and MUN concentrations indicate improved N efficiency (Broderick and Clayton, 1997; Nousiainen et al., 2004). In the present trial, CO reduced $(P<0.01)$ both BUN and MUN (Table 3), which suggested a more efficient utilization of dietary $\mathrm{N}$ for milk protein secretion. However, no differences between the $\mathrm{CO}$ treatment and control were detected in either milk protein yield or in milk $\mathrm{N} / \mathrm{N}$ intake (Table
$3)$. In the present trial, no differences in BW change were noted across treatments (Table 3). Perhaps improved $\mathrm{N}$ utilization, as indicated by reductions in BUN and MUN observed in the current experiment, was insufficient to allow higher milk protein production. In agreement with these findings, Lee et al. (2011) have shown similar reductions in MUN and BUN, but no changes in BW with La supplementation.

A decrease of about $40 \%$ in RP population $(P<$ 0.01) was observed when cows ingested $291 \mathrm{~g} / \mathrm{d}$ of La or $690 \mathrm{~g} / \mathrm{d}$ of CO, which provided $276 \mathrm{~g} / \mathrm{d}$ of La (Table 4). Similarly, Faciola et al. (2013) observed a decrease of $32 \%$ in RP numbers when $243 \mathrm{~g} / \mathrm{d}$ of La was ingested by dairy cows. Faciola and Broderick (2013) observed reductions of 37 and $67 \%$ when 129 and $270 \mathrm{~g} / \mathrm{d}$ of La were consumed, respectively (experiment 1), and reductions of 28 and $49 \%$ when 220 and $404 \mathrm{~g} / \mathrm{d}$ of La were consumed, respectively (experiment 2). The greater antiprotozoal effect of La observed in experiment 1 was probably a consequence of lower DMI in that trial, which would have concentrated La within the rumen. Reduction of RP numbers by La and $\mathrm{CO}$ has been reported consistently. Hristov et al. (2009) observed an $80 \%$ reduction in RP numbers when 240 $\mathrm{g} / \mathrm{d}$ of La or $530 \mathrm{~g} / \mathrm{d}$ of CO were dosed directly into the rumen of dairy cows immediately before feeding. Furthermore, Hristov et al. (2011) observed a 96\% reduction in RP numbers when $240 \mathrm{~g} / \mathrm{d}$ of La was dosed into the rumen of dairy cows before feeding. Faciola et al. (2013) observed a 90\% reduction in RP numbers when $160 \mathrm{~g} / \mathrm{d}$ of La was dosed into the rumen of dairy cows before feeding. Lee et al. (2011) observed a $60 \%$ reduction in RP numbers when $500 \mathrm{~g} / \mathrm{d}$ of $\mathrm{CO}$ was consumed mixed in the TMR of dairy cows. Reveneau et al. (2012) reported a 90\% reduction in RP population when $5 \%$ CO was added to the diet of lactating dairy cows. These results again indicate that delivery method and dose of La and CO both play a role in the degree of RP population suppression.

Ruminal ammonia concentration was reduced when $\mathrm{CO}$ and La were fed $(P<0.01)$, whereas total free AA concentration was only reduced by La consumption $(P<0.01$; Table 4$)$. One of the most common findings associated with reduced RP population has been decreased ruminal ammonia (Williams and Coleman, 1992; Jouany, 1996). Faciola and Broderick (2013) reported reductions in both ruminal ammonia and total free AA concentration when La was consumed by dairy cows. Lee et al. (2011) found a trend toward reducing ruminal ammonia concentration and no change on TAA concentration when the RP population was suppressed $60 \%$ with the feeding of $500 \mathrm{~g} / \mathrm{d}$ of CO to dairy cows. Ruminal protozoa possess protease (Forsberg et al., 1984), peptidase (Newbold et al., 1989), and de- 
Table 4. Effects of feeding lauric acid (La) or coconut oil $(\mathrm{CO})$ on ruminal traits ${ }^{1}$

\begin{tabular}{lccccc}
\hline & \multicolumn{3}{c}{ Diet } & & \\
\cline { 2 - 4 } Item & Control & La & CO & SEM & $P$-value \\
\hline La intake, g/d & 0 & 291 & 276 & & - \\
pH & 6.16 & 6.11 & 6.17 & 0.07 & 0.34 \\
Total VFA, mM & $127.5^{\mathrm{a}}$ & $122.8^{\mathrm{b}}$ & $123.5^{\mathrm{b}}$ & 3.8 & $<0.01$ \\
Acetate, \% of total VFA & $65.0^{\mathrm{a}}$ & $63.7^{\mathrm{b}}$ & $62.6^{\mathrm{b}}$ & 1.1 & 0.05 \\
Propionate, \% of total VFA & $19.5^{\mathrm{b}}$ & $20.4^{\mathrm{b}}$ & $22.0^{\mathrm{a}}$ & 1.3 & 0.05 \\
Acetate:propionate & $3.3^{\mathrm{a}}$ & $3.1^{\mathrm{b}}$ & $2.8^{\mathrm{c}}$ & 0.1 & $<0.01$ \\
Butyrate, \% of total VFA & 11.7 & 11.6 & 11.3 & 0.6 & 0.11 \\
Valerate, \% of total VFA & $1.75^{\mathrm{b}}$ & $1.84^{\mathrm{ab}}$ & $1.94^{\mathrm{a}}$ & 0.15 & 0.04 \\
Isovalerate, \% of total VFA & $1.71^{\mathrm{a}}$ & $1.61^{\mathrm{b}}$ & $1.66^{\mathrm{ab}}$ & 0.08 & 0.05 \\
Isobutyrate + 2-methylbutyrate, \% of total VFA & $1.07^{\mathrm{a}}$ & $0.96^{\mathrm{b}}$ & $0.94^{\mathrm{b}}$ & 0.09 & $<0.01$ \\
Branched-chain VFA, \% of total VFA & $2.78^{\mathrm{a}}$ & $2.57^{\mathrm{b}}$ & $2.60^{\mathrm{b}}$ & 0.13 & $<0.01$ \\
Ammonia, m $M$ & $10.4^{\mathrm{a}}$ & $9.1^{\mathrm{c}}$ & $9.6^{\mathrm{b}}$ & 0.4 & $<0.01$ \\
Total free AA, m $M$ & $5.2^{\mathrm{a}}$ & $4.2^{\mathrm{b}}$ & $5.3^{\mathrm{a}}$ & 0.5 & $<0.01$ \\
Protozoa, $\times 10^{6}$ cells $/ \mathrm{mL}$ & $5.71^{\mathrm{a}}$ & $3.45^{\mathrm{b}}$ & $3.29^{\mathrm{b}}$ & 0.21 & $<0.01$ \\
\hline
\end{tabular}

${ }^{\mathrm{a}-\mathrm{c}}$ Least squares means within the same row with different superscripts differ $(P<0.05)$.

${ }^{1}$ Data from the 6 ruminally cannulated cows.

aminase (Itabashi and Kandatsu, 1975) activities. Hino and Russell (1987) reported that deaminase activity in protozoal extracts was 2 to 3 times higher than in bacterial extracts; therefore, RP appear to degrade dietary protein, peptides and AA. Moreover, protozoa briskly consume bacteria (Coleman, 1975) and in vitro studies indicated that they are the main contributors to bacterial protein turnover in rumen fluid (Wallace and McPherson, 1987). These observations help to explain why suppression of RP population often reduces ruminal ammonia concentration.

Ruminal $\mathrm{pH}$ was not affected $(P=0.34)$ by La or CO feeding in this trial, which agrees with previous observations of Faciola and Broderick (2013). In the present trial, ruminal total VFA concentration was reduced $(P$ $<0.01$ ) when La and CO were consumed (Table 4), but a reduction from 128 to $123 \mathrm{~m} M$ probably is of marginal biological significance.

Ruminal propionate molar proportion increased $(P$ $=0.05)$ and acetate-to-propionate ratio decreased $(P$ $<0.01$ ) when $\mathrm{CO}$ was consumed compared with both control and La treatments (Table 4). Molar proportion of acetate also was reduced by $\mathrm{La}(P=0.05)$. Similar results were reported by Storry et al. (1974) and Lee et al. (2011). These results indicated that partial RP suppression leads to greater propionate and lower acetate proportions in ruminal VFA, which may be explained by the lower NDF digestion observed with RP suppression and also by the observation that RP produce predominantly acetate (Williams and Coleman, 1992). Ruminal isobutyrate molar proportion was reduced $(P$ $<0.01$ ) by both La and $\mathrm{CO}$; moreover, La reduced ruminal isovalerate plus 2-methylbutyrate molar proportion $(P=0.05)$ (Table 4$)$. These branched-chain VFA (BCVFA) are formed in the rumen by deamination of branched-chain AA and concentrations are related to ruminal degradation of dietary protein (Van Soest, 1994). Literature data on the effects of RP suppression on BCVFA are scarce and, because of their very low molar concentration and analytical variations, it has been often difficult to detect statistical differences. Hristov et al. (2011) also reported reduced ruminal isobutyrate concentration when La was dosed directly into the rumen before feeding. Suppression of RP, which has been commonly shown to reduce proteolysis, deamination, and microbial recycling (Wallace et al., 1987; Broderick et al., 1991; Ushida et al., 1991), is likely to reduce BCVFA, and lower BCVFA concentrations may also reflect lower microbial turnover in the rumen. Because of the inconsistencies observed in individual VFA molar proportions reported in RP suppression studies, Veira (1986) suggested that RP per se may not be solely responsible for the observed differences but rather that changes in the bacterial population, often not measured, probably also play a role in VFA pattern and concentration.

In the present study, apparent digestibility of NDF and ADF was reduced $(P<0.01)$ when La, but not CO, was fed (Table 5). Reduction in apparent NDF digestibility after La treatment has been observed (Faciola and Broderick, 2013; Faciola et al., 2013); moreover, similar results have recently been reported after CO feeding (Lee et al., 2011; Hollmann and Beede, 2012; Reveneau et al., 2012). Reduction in NDF digestibility appears to be an effect frequently reported in RP suppression studies (Williams and Coleman, 1992). This could be a result of several factors. Rumen protozoa have been shown to possess cellulase (Hungate, 1966), hemicellulase (Williams and Coleman, 1985), and pectinase (Orpin and Hall, 1983; Orpin, 1984) activities, 
Table 5. Effects of feeding lauric acid (La) or coconut oil (CO) on apparent digestibility and $\mathrm{N}$ excretion ${ }^{1}$

\begin{tabular}{|c|c|c|c|c|c|}
\hline \multirow[b]{2}{*}{ Item } & \multicolumn{3}{|c|}{ Diet } & \multirow[b]{2}{*}{ SEM } & \multirow[b]{2}{*}{$P$-value } \\
\hline & Control & $\mathrm{La}$ & $\mathrm{CO}$ & & \\
\hline La intake, $\mathrm{g} / \mathrm{d}$ & 0 & 288 & 275 & - & - \\
\hline \multicolumn{6}{|l|}{ Apparent digestibility, \% } \\
\hline DM & 67.3 & 66.4 & 67.2 & 1.0 & 0.13 \\
\hline OM & 69.4 & 68.5 & 69.5 & 1.0 & 0.13 \\
\hline $\mathrm{NDF}$ & $44.4^{\mathrm{a}}$ & $41.9^{\mathrm{b}}$ & $44.3^{\mathrm{a}}$ & 1.0 & $<0.01$ \\
\hline $\mathrm{ADF}$ & $49.3^{\mathrm{a}}$ & $46.1^{\mathrm{b}}$ & $48.5^{\mathrm{a}}$ & 1.0 & $<0.01$ \\
\hline $\mathrm{CP}$ & 62.7 & 63.8 & 63.9 & 1.1 & 0.12 \\
\hline \multicolumn{6}{|l|}{ Excretion } \\
\hline Urine volume, ${ }^{2} \mathrm{~L} / \mathrm{d}$ & 22.5 & 23.1 & 21.8 & 1.2 & 0.21 \\
\hline Urinary urea-N, $\mathrm{g} / \mathrm{d}$ & 136 & 138 & 131 & 3.2 & 0.16 \\
\hline Total urinary $\mathrm{N}, \mathrm{g} / \mathrm{d}$ & 166 & 164 & 161 & 3.1 & 0.23 \\
\hline Urea-N/total urinary-N, \% & 82.0 & 84.4 & 81.2 & 2.7 & 0.17 \\
\hline Allantoin, $\mathrm{mmol} / \mathrm{d}$ & 400 & 396 & 408 & 7.1 & 0.32 \\
\hline Uric acid, $\mathrm{mmol} / \mathrm{d}$ & 35.4 & 35.2 & 35.5 & 4.2 & 0.28 \\
\hline Purine derivative, ${ }^{3} \mathrm{mmol} / \mathrm{d}$ & 435.4 & 431.2 & 443.5 & 15.1 & 0.16 \\
\hline Fecal N/urinary N & 1.30 & 1.27 & 1.32 & 0.26 & 0.15 \\
\hline Milk N/fecal + urinary $\mathrm{N}$ & 0.43 & 0.42 & 0.44 & 0.03 & 0.13 \\
\hline Microbial N flow, ${ }^{4} \mathrm{~g} / \mathrm{d}$ & 249 & 246 & 255 & 17.0 & 0.23 \\
\hline Apparent $\mathrm{N}$ balance,$^{5} \mathrm{~g} / \mathrm{d}$ & 46 & 58 & 67 & 16.0 & 0.11 \\
\hline \multirow{2}{*}{\multicolumn{6}{|c|}{ a,b Least squares means within the same row with different superscripts differ $(P<0.05)$}} \\
\hline \multirow{2}{*}{\multicolumn{6}{|c|}{$\begin{array}{l}{ }^{1} \text { Data from } 30 \text { lactating cows. } \\
{ }^{2} \text { Estimated from creatinine concentration in spot urine samples assuming an excretion of } 29 \mathrm{mg} \text { of creatinine } \\
\mathrm{kg} \text { of BW (Valadares et al., 1999). }\end{array}$}} \\
\hline & & & & & \\
\hline \multicolumn{6}{|c|}{${ }^{3}$ Allantoin plus uric acid. } \\
\hline \multicolumn{6}{|c|}{${ }^{4}$ Estimated from urinary excretion of purine derivatives according to Valadares et al. (1999). } \\
\hline
\end{tabular}

which may explain their role in NDF digestion. Rumen protozoa may also affect the extent of fiber fermentation. Hristov et al. (2004) reported a decrease in carboxymethylcellulase, a measure of total fibrolytic activity, when RP was suppressed by $91 \%$ of the control diet. Reductions in NDF and ADF digestion observed when La was fed may explain the reduction of the molar proportion of acetate (Table 4). Because acetate is a major precursor for FA synthesis in ruminants, its reduction may help explain the lower milk fat percentage observed when La was consumed.

No differences in ruminal microbial $\mathrm{N}$ flow were observed among treatments when estimated from urinary excretion of purine derivatives (Valadares et al.,1999; Table 5) or when it was measured from ${ }^{15} \mathrm{~N}$ enrichment of microbial NAN at the omasal canal. Ruminal microbial $\mathrm{N}$ flow determined using purine derivative excretion underestimated microbial $\mathrm{N}$ flow by about $30 \%$ when compared with omasal flow measured using ${ }^{15} \mathrm{~N}$ as a microbial marker, a result that agrees with the observations of Reynal et al. (2005). Among possible reasons for these differences could be (1) physiological differences between the animals used in the present experiment and those used to develop the relationships between purine derivative excretion and ruminal purine outflow, and (2) inaccuracies in spot urine sample collections.
A trend $(P=0.06)$ was noted for reduced omasal DM flow when La was fed (Table 6); however, no differences in DM apparently digested in the rumen and no differences in OM omasal flow or OM digestion in the rumen were observed when either La or $\mathrm{CO}$ were consumed. Lauric acid reduced NDF and ADF apparently digested in the rumen $(P<0.01)$ and increased the flow of NDF $(P=0.05)$ at the omasal canal. Data on omasal flow and apparent ruminal digestion of DM, OM, NDF, and ADF with La feeding has not, to our knowledge, been previously reported in the scientific literature. Ruminal fiber digestion accounts for the major portion of the total tract digestion (Ahvenjärvi et al., 2000). Feeding La was shown to decrease total tract fiber digestion in the present study, as presented earlier but also in other studies (Faciola and Broderick, 2013; Faciola et al., 2013); therefore, reduced ruminal fiber digestion would be expected to be with associated with reduced protozoal population in the rumen. Reveneau et al. (2012) reported numerically but not significantly different ruminal NDF digestion when feeding $\mathrm{CO}$ and using $\mathrm{YbCl}_{3}$ as a single solid marker (labeled corn silage), Co-EDTA as the liquid marker, and dosing markers 3 times daily as opposed to the continuous infusion applied in the present study. Thus, different marker methodology used may explain some of these differences. 
Table 6. Effects of feeding lauric acid (La) or coconut oil (CO) on intake, flow at the omasal canal, and ruminal digestibility of DM, OM, NDF, and $\mathrm{ADF}^{1}$

\begin{tabular}{|c|c|c|c|c|c|}
\hline \multirow[b]{2}{*}{ Item } & \multicolumn{3}{|c|}{ Diet } & \multirow[b]{2}{*}{ SEM } & \multirow[b]{2}{*}{$P$-value } \\
\hline & Control & La & $\mathrm{CO}$ & & \\
\hline La intake, $g / d$ & 0 & 291 & 276 & - & - \\
\hline \multicolumn{6}{|l|}{ DM } \\
\hline Intake, $\mathrm{kg} / \mathrm{d}$ & 22.8 & 22.4 & 23.0 & 1.0 & 0.14 \\
\hline Flow at the omasal canal, $\mathrm{kg} / \mathrm{d}$ & 14.1 & 13.6 & 14.2 & 0.7 & 0.06 \\
\hline Apparently digested in the rumen, $\mathrm{kg} / \mathrm{d}$ & 8.68 & 8.77 & 8.76 & 0.82 & 0.21 \\
\hline$\%$ of DMI & 38.1 & 39.1 & 38.1 & 2.5 & 0.18 \\
\hline \multicolumn{6}{|l|}{$\mathrm{OM}$} \\
\hline Intake, $\mathrm{kg} / \mathrm{d}$ & 21.2 & 20.8 & 21.4 & 0.93 & 0.08 \\
\hline Flow at omasal canal, $\mathrm{kg} / \mathrm{d}$ & 11.4 & 11.1 & 11.5 & 0.62 & 0.18 \\
\hline Apparently digested in the rumen, $\mathrm{kg} / \mathrm{d}$ & 9.78 & 9.77 & 9.88 & 0.42 & 0.17 \\
\hline$\%$ of OM intake & 46.1 & 46.9 & 46.2 & 1.1 & 0.16 \\
\hline Truly digested in the rumen, $\mathrm{kg} / \mathrm{d}$ & 13.5 & 13.4 & 13.6 & 0.71 & 0.19 \\
\hline$\%$ of OM intake & 63.6 & 64.4 & 63.7 & 2.4 & 0.21 \\
\hline \multicolumn{6}{|l|}{ NDF } \\
\hline Intake, $\mathrm{kg} / \mathrm{d}$ & 6.48 & 6.43 & 6.53 & 0.25 & 0.16 \\
\hline Flow at the omasal canal, $\mathrm{kg} / \mathrm{d}$ & $4.61^{\mathrm{b}}$ & $4.82^{\mathrm{a}}$ & $4.64^{\mathrm{ab}}$ & 0.19 & 0.05 \\
\hline Apparently digested in the rumen, $\mathrm{kg} / \mathrm{d}$ & $1.87^{\mathrm{a}}$ & $1.61^{\mathrm{b}}$ & $1.89^{\mathrm{a}}$ & 0.16 & $<0.01$ \\
\hline$\%$ of NDF intake & $28.8^{\mathrm{a}}$ & $25.0^{\mathrm{b}}$ & $29.0^{\mathrm{a}}$ & 2.1 & $<0.01$ \\
\hline \multicolumn{6}{|l|}{$\mathrm{ADF}$} \\
\hline Intake, $\mathrm{kg} / \mathrm{d}$ & 4.20 & 4.12 & 4.23 & 0.17 & 0.15 \\
\hline Flow at the omasal canal, $\mathrm{kg} / \mathrm{d}$ & 2.96 & 3.08 & 3.01 & 0.13 & 0.07 \\
\hline Apparently digested in the rumen, $\mathrm{kg} / \mathrm{d}$ & $1.24^{\mathrm{a}}$ & $1.04^{\mathrm{b}}$ & $1.22^{\mathrm{a}}$ & 0.10 & $<0.01$ \\
\hline$\%$ of ADF intake & $29.4^{\mathrm{a}}$ & $25.2^{\mathrm{b}}$ & $28.9^{\mathrm{a}}$ & 2.3 & $<0.01$ \\
\hline
\end{tabular}

Trends for increased $\mathrm{N}$ truly digested in the rumen $(P=0.07)$ and decreased RUP flow at the omasal canal $(P=0.08)$ were observed when $\mathrm{CO}$ was consumed (Table 7), which may be a reflection of the trend toward increased RDP supply $(P=0.09)$ on the CO treatment. Diets were formulated to provide similar amounts of RDP and RUP, and, although not significant, small numerical differences in DMI, and therefore $\mathrm{N}$ intake, may explain the observed trends in RDP supply and RUP flow. Increased RUP flow previously reported with RP suppression (Jouany, 1996) was not observed in the present study; $40 \%$ suppression in RP population may not have been enough to promote this effect. No differences were observed in NAN flowing with fluidand particle-associated bacteria in the current study (Table 7). It is not clearly understood how suppressing RP would affect different types of bacteria. Studies reporting differences in the bacterial community were often done in vitro and with complete elimination of the RP population (Ushida et al., 1987), conditions very different from the current study. In our study, suppression of $40 \%$ of RP population did not change total microbial NAN flow and microbial efficiency, measured as microbial NAN per unit of OM truly digested in the rumen (Table 7). Ivan (2009) observed decreased total NAN and bacterial NAN flow when RP were inoculated into RP-free sheep, which suggests a beneficial effect of suppressing RP in vivo. However, achieving such effects in a practical setting without the negative effects of various RP-suppressant agents on DMI, ruminal fermentation, and nutrient and fiber digestion remains a challenge.

\section{CONCLUSIONS}

Results from our experiment have confirmed that dietary La is not practical for suppressing RP population in lactating dairy cows, mainly because of its negative effects on fiber digestion, ruminal fermentation, and, consequently, milk production. Consumption of $\mathrm{CO}$ at $687 \mathrm{~g} / \mathrm{d}$ or La at $288 \mathrm{~g} / \mathrm{d}$ mixed in the TMR did not reduce DMI of lactating dairy cows. However, feeding La reduced yields of milk, 3.5\% FCM, fat, protein, lactose, and SNF. Lauric acid also reduced the efficiency of conversion of energy and $\mathrm{N}$ into milk. Despite not affecting DMI, reducing ruminal ammonia, MUN, and BUN concentrations, and increasing molar proportions of propionate, feeding CO reduced efficiency of conversion of feed energy into milk, did not improve yield of milk and milk components, and did not increase microbial synthesis in the rumen. Lauric acid markedly reduced ruminal and total tract apparent digestibility of NDF and ADF. Both La and CO reduced ruminal total VFA concentration, molar proportions of acetate, and acetate-to-propionate ratio. Lauric acid consumption increased NDF flow at the omasal canal. Both $\mathrm{CO}$ 
Table 7. Effects of feeding lauric acid (La) or coconut oil (CO) on intake and flow of $\mathrm{N}$ fractions at the omasal canal $^{1}$

\begin{tabular}{|c|c|c|c|c|c|}
\hline \multirow[b]{2}{*}{ Item $^{2}$} & \multicolumn{3}{|c|}{ Diet } & \multirow[b]{2}{*}{ SEM } & \multirow[b]{2}{*}{$P$-value } \\
\hline & Control & $\mathrm{La}$ & $\mathrm{CO}$ & & \\
\hline La intake, $\mathrm{g} / \mathrm{d}$ & 0 & 291 & 276 & - & - \\
\hline Dietary $\mathrm{N}$ intake, $\mathrm{g} / \mathrm{d}$ & 587 & 581 & 592 & 14 & 0.11 \\
\hline \multicolumn{6}{|l|}{ Omasal flows } \\
\hline Total NAN, g/d & 523 & 522 & 525 & 25 & 0.19 \\
\hline $\mathrm{NAN}^{2} \%$ of N intake & 89.1 & 89.9 & 88.7 & 2.1 & 0.16 \\
\hline $\mathrm{N}$ truly digested in the rumen, $\mathrm{g} / \mathrm{d}$ & 414 & 404 & 423 & 23 & 0.07 \\
\hline \multicolumn{6}{|l|}{ RDP supply } \\
\hline $\mathrm{kg} / \mathrm{d}$ & 2.52 & 2.46 & 2.58 & 0.15 & 0.09 \\
\hline$\%$ of $\operatorname{diet} \mathrm{CP}$ & 68.7 & 67.7 & 69.6 & 2.2 & 0.08 \\
\hline$\%$ of DMI & 11.0 & 10.9 & 11.2 & 0.4 & 0.06 \\
\hline \multicolumn{6}{|l|}{ RUP flow } \\
\hline $\mathrm{kg} / \mathrm{d}$ & 1.15 & 1.17 & 1.13 & 0.06 & 0.08 \\
\hline$\%$ of $\operatorname{diet} \mathrm{CP}$ & 31.3 & 32.3 & 30.4 & 2.1 & 0.07 \\
\hline \% of DMI & 5.0 & 5.2 & 4.9 & 0.5 & 0.09 \\
\hline \multicolumn{6}{|l|}{ NMNAN flow } \\
\hline $\mathrm{g} / \mathrm{d}$ & 173 & 176 & 169 & 15 & 0.16 \\
\hline$\%$ of total NAN & 33.1 & 33.8 & 32.2 & 1.8 & 0.08 \\
\hline$\%$ of $\mathrm{N}$ intake & 29.5 & 30.4 & 28.5 & 2.1 & 0.08 \\
\hline \multicolumn{6}{|l|}{ Microbial NAN flows } \\
\hline \multicolumn{6}{|l|}{ FAB-NAN } \\
\hline $\mathrm{g} / \mathrm{d}$ & 152 & 149 & 155 & 10 & 0.13 \\
\hline$\%$ of microbial-NAN & 43.4 & 43.2 & 43.5 & 1.8 & 0.32 \\
\hline \multicolumn{6}{|l|}{ PAB-NAN } \\
\hline $\mathrm{g} / \mathrm{d}$ & 198 & 196 & 201 & 16 & 0.16 \\
\hline$\%$ of microbial-NAN & 56.6 & 56.8 & 56.5 & 1.7 & 0.23 \\
\hline \multicolumn{6}{|l|}{ Total microbial NAN } \\
\hline $\mathrm{g} / \mathrm{d}$ & 350 & 345 & 356 & 19 & 0.12 \\
\hline$\%$ of total NAN & 66.9 & 66.2 & 67.8 & 1.9 & 0.11 \\
\hline Microbial efficiency, $\mathrm{g}$ of NAN/kg of OMTDR & 26.0 & 25.7 & 26.1 & 0.7 & 0.12 \\
\hline
\end{tabular}

and La reduced RP numbers by about $40 \%$; therefore, based on the results of our study, a $40 \%$ reduction of $\mathrm{RP}$ population is not sufficient to improve $\mathrm{N}$ utilization in dairy cows.

\section{ACKNOWLEDGMENTS}

The authors thank Elliott Block and Arm \& Hammer Animal Nutrition (Princeton, NJ) for providing Megalac for the study; the farm crew for harvesting and storing the feedstuffs used in this trial and J. Meronek and the barn crew for feeding and animal care at the U.S. Dairy Forage Center Research Farm (Prairie du Sac, WI); and W. Radloff and M. Becker (US Dairy Forage Research Center) for conducting laboratory analyses and for assisting with sampling collection.

\section{REFERENCES}

Ahvenjärvi, S., A. Vanhatalo, P. Huhtanen, and T. Varvikko. 2000. Determination of reticulo-rumen and whole-stomach digestion in lactating cows by omasal canal or duodenal sampling. Br. J. Nutr. $83: 67-77$.
AOAC. 1980. Official Methods of Analysis 13th ed. Assoc. Off. Anal. Chem., Arlington, VA.

AOAC. 1990. Official Methods of Analysis 15th ed. Vol 1. Assoc. Off. Anal. Chem., Arlington, VA.

Brito, A. F., G. A. Broderick, and S. M. Reynal. 2007. Effects of different protein supplements on omasal nutrient flow and microbial protein synthesis in lactating dairy cows. J. Dairy Sci. 90:18281841.

Broderick, G. A. 1987. Determination of protein degradation rates using a rumen in vitro system containing inhibitors of microbial nitrogen metabolism. Br. J. Nutr. 58:463-475.

Broderick, G. A., and M. K. Clayton. 1997. A statistical evaluation of animal and nutritional factors influencing concentrations of milk urea nitrogen. J. Dairy Sci. 80:2964-2971.

Broderick, G. A., and W. J. Radloff. 2004. Effect of molasses supplementation on the production of lactating dairy cows fed diets based on alfalfa and corn silage. J. Dairy Sci. 87:2997-3009.

Broderick, G. A., R. J. Wallace, and E. R. Ørskov. 1991. Control of rate and extent of protein degradation. Pages 541-592 in Physiological Aspects of Digestion and Metabolism in Ruminants. T. Tsuda, Y. Sasaki, and R. Kawashima, ed. Academic Press Inc., Orlando, FL.

Brotz, P. G., and D. M. Schaefer. 1987. Simultaneous determination of lactic acid and volatile fatty acids in microbial fermentation extracts by gas-liquid chromatography. J. Microbiol. Methods 6:139-144

Cochran, R. C., D. C. Adams, J. D. Wallace, and M. L. Galyean. 1986. Predicting digestibility of different diets with internal markers: Evaluation of four potential markers. J. Anim. Sci. 63:1476-1487. 
Coleman, G. S. 1975. The interrelationships between rumen ciliate protozoa and bacteria. Pages 149-164 in Digestion and Metabolism in the Ruminant. I. W. McDonald and A. C. Warner, ed. University of New England Publishing Unit, Armidale, Australia.

Dehority, B. A. 1993. Laboratory Manual for Classification and Morphology of Rumen Ciliate Protozoa. CRC Press, Boca Raton, FL.

Faciola, A. P., and G. A. Broderick. 2013. Effects of feeding lauric acid on ruminal protozoa numbers, fermentation, digestion, and on milk production in dairy cows. J. Anim. Sci. 91:2243-2253.

Faciola, A. P., G. A. Broderick, A. Hristov, and M. I. Leão. 2013. Effects of lauric acid on ruminal protozoal numbers and fermentation pattern and milk production in lactating dairy cows. J. Anim. Sci. 91:363-373.

Forsberg, C. W., L. K. Lovelock, L. Krumholz, and J. G. BuchananSmith. 1984. Protease activities of rumen protozoa. Appl. Environ. Microbiol. 47:101-110.

Fox, D. G., L. O. Tedeschi, T. P. Tylutki, J. B. Russell, M. E. Van Amburgh, L. E. Chase, A. N. Pell, and T. R. Overton. 2004. The Cornell Net Carbohydrate and Protein System model for evaluating herd nutrition and nutrient excretion. Anim. Feed Sci. Technol. 112:29-78.

France, J., and R. C. Siddons. 1986. Determination of digesta flow by continuous marker infusion. J. Theor. Biol. 121:105-119.

Hino, T., and J. B. Russell. 1987. Relative contributions of ruminal bacteria and protozoa to the degradation of protein in vitro. J. Anim. Sci. 64:261-270.

Hintz, R. W., D. R. Mertens, and K. A. Albrecht. 1996. Effects of sodium sulfite on recovery and composition of detergent fiber and lignin. J. AOAC Int. 79:16-22.

Hollmann, M., and D. K. Beede. 2012. Comparison of effects of dietary coconut oil and animal fat blend on lactational performance of Holstein cows fed a high-starch diet. J. Dairy Sci. 95:1484-1499.

Hristov, A. N., K. L. Grandeen, J. K. Ropp, and M. A. McGuire. 2004 Effect of sodium laurate on ruminal fermentation and utilization of ruminal ammonia nitrogen for milk protein synthesis in dairy cows. J. Dairy Sci. 87:1820-1831.

Hristov, A. N., C. Lee, T. Cassidy, M. Long, K. Heyler, B. Corl, and R. Forster. 2011. Effects of lauric and myristic acids on ruminal fermentation, production, and milk fatty acid composition in lactating dairy cows. J. Dairy Sci. 94:382-395.

Hristov, A. N., M. Vander Pol, M. Agle, S. Zaman, C. Schneider, P. Ndegwa, V. K. Vaddella, K. Johnson, K. J. Shingfield, and S. K. R. Karnati. 2009. Effect of lauric acid and coconut oil on ruminal fermentation, digestion, ammonia losses from manure, and milk fatty acid composition in lactating cows. J. Dairy Sci. 92:55615582 .

Huhtanen, P., P. G. Brotz, and L. D. Satter. 1997. Omasal sampling technique for assessing fermentative digestion in the forestomach of dairy cows. J. Anim. Sci. 75:1380-1392.

Huhtanen, P., K. Kaustell, and S. Jaakkola. 1994. The use of internal markers to predict total digestibility and duodenal flow of nutrients in cattle given six different diets. Anim. Feed Sci. Technol. 48:211-227.

Hungate, R. E. 1966. The Rumen and its Microbes. Academic Press, New York, NY.

Itabashi, H., and M. Kandatsu. 1975. Influence of rumen ciliate protozoa on the concentration of free amino acids in the rumen fluids. Jpn. J. Zootech. Sci. 46:600-606.

Ivan, M. 2009. Comparison of duodenal flow and digestibility in faunafree sheep inoculated with Holotrich protozoa, Entodinium monofauna or total mixed protozoa population. Br. J. Nutr. 101:34-40.

Jordan, E., D. K. Lovett, F. J. Monahan, J. Callan, B. Flynn, and F. P. O'Mara. 2006. Effect of refined coconut oil or copra meal on methane output and on intake and performance of beef heifers. J. Anim. Sci. 84:162-170.

Jouany, J. P. 1996. Effect of rumen protozoa on nitrogen utilization by ruminants. J. Nutr. 126(Suppl.):1335S-1346S

Lee, C., A. N. Hristov, K. S. Heyler, T. W. Cassidy, M. Long, B. A Corl, and S. K. R. Karnati. 2011. Effects of dietary protein concentration and coconut oil supplementation on nitrogen utilization and production in dairy cows. J. Dairy Sci. 94:5544-5557.
Muck, R. E. 1987. Dry matter level effects on alfalfa silage quality. 1. Nitrogen transformations. Trans. ASAE 30:7-14.

Newbold, C. J., and D. G. Chamberlain. 1988. Lipids as rumen-defaunating agents. Proc. Nutr. Soc. 43:154A.

Newbold, C. J., N. McKain, and R. J. Wallace. 1989. The role of protozoa in ruminal peptide metabolism. Pages $42-55$ in Biochemistry and Molecular Biology of "Anaerobic" Protozoa. D. Lloyd, G. H. Coombs, and T. A. Paget, ed. Harwood Academic Press, London, UK.

Nousiainen, J., K. J. Shingfield, and P. Huhtanen. 2004. Evaluation of milk urea nitrogen as a diagnostic of protein feeding. J. Dairy Sci. 87:386-398.

NRC. 2001. Nutrient Requirements of Dairy Cattle. 7th rev. ed. Natl. Acad. Press, Washington, DC.

Onetti, S. G., R. D. Shaver, S. J. Bertics, and R. R. Grummer. 2003. Influence of corn silage particle length on the performance of lactating dairy cows fed supplemental tallow. J. Dairy Sci. 86:29492957.

Orpin, C. G. 1984. The role of ciliate protozoa and fungi in the rumen digestion of plant-cell walls. Anim. Feed Sci. Technol. 10:121-143.

Orpin, C. G., and F. J. Hall. 1983. Surface-structures of the rumen holotrich protozoan Isotricha intestinalis with particular reference to the attachment zone. Curr. Microbiol. 8:321-325.

Oser, B. L. 1965. Hawk's Physiological Chemistry. 14th ed. McGrawHill, New York, NY.

Reveneau, C., S. K. Karnati, E. R. Oelker, and J. L. Firkins. 2012. Interaction of unsaturated fat or coconut oil with monensin in lactating dairy cows fed 12 times daily. I. Protozoal abundance, nutrient digestibility, and microbial flow to the omasum. J. Dairy Sci. 95:2046-2060.

Reynal, S. M., and G. A. Broderick. 2005. Effect of dietary level of rumen-degraded protein on production and nitrogen metabolism in lactating dairy cows. J. Dairy Sci. 88:4045-4064.

Reynal, S. M., G. A. Broderick, and C. Bearzi. 2005. Comparison of four markers for quantifying microbial protein flow from the rumen of lactating dairy cows. J. Dairy Sci. 88:4065-4082.

Roth, M. 1971. Fluorescence reaction of amino acids. Anal. Chem. 43:880-882.

Siddons, R. C., J. Paradine, D. E. Beever, and P. R. Cornell. 1985. Ytterbium acetate as a particulate-phase digesta-flow marker. Br. J. Nutr. 54:509-519.

Sklan, D., R. Ashkenazi, A. Braun, A. Devorin, and K. Tabori. 1992. Fatty acids, calcium soaps of fatty acids, and cottonseeds fed to high-yielding cows. J. Dairy Sci. 75:2463-2472.

Storry, J. E., P. E. Brumby, A. J. Hall, and V. W. Johnson. 1974. Response of lactating cow to different methods of incorporating casein and coconut oil in the diet. J. Dairy Sci. 57:61-67.

Sukhija, P. S., and D. L. Palmquist. 1988. Rapid method for determination of total fatty acid content and composition in feedstuffs and feces. J. Agric. Food Chem. 36:1202-1206.

Udén, P., P. E. Colucci, and P. J. van Soest. 1980. Investigation of chromium, cerium and cobalt as markers in digesta. Rate of passage studies. J. Sci. Food Agric. 31:625-632.

Ushida, K., J. P. Jouany, and D. I. Demeyer. 1991. Effects of presence or absence of rumen protozoa on the efficiency of utilization of concentrate and fibrous feeds. Pages 625-654 in Physiological Aspects of Digestion and Metabolism in Ruminants. T. Tsuda, Y. Sasaki, and R. Kawashima, ed. Academic Press Inc., Orlando, FL.

Ushida, K., T. Kaneko, and Y. Kojina. 1987. Effect of presence of large entodiniomorphid protozoa on the rumen bacterial flora, fauna composition of small entodinia and in vitro cellulolysis and xylanolysis. Jpn. J. Zootech. Sci. 58:893-902.

Valadares, R. F. D., G. A. Broderick, S. C. Valadares, and M. K. Clayton. 1999. Effect of replacing alfalfa silage with high moisture corn on ruminal protein synthesis estimated from excretion of total purine derivatives. J. Dairy Sci. 82:2686-2696.

Van Soest, P. J. 1994. Nutritional Ecology of the Ruminant. 2nd ed. O \& B Books Inc., Corvallis, OR.

Van Soest, P. J., J. B. Robertson, and B. A. Lewis. 1991. Methods for dietary fiber, neutral detergent fiber, and nonstarch polysaccharides in relation to animal nutrition. J. Dairy Sci. 74:3583-3597. 
Veira, D. M. 1986. The role of ciliate protozoa in nutrition of the ruminant. J. Anim. Sci. 63:1547-1560.

Vogels, G. D., and C. van der Grift. 1970. Differential analyses of glyoxylate derivatives. Anal. Biochem. 33:143-157.

Wallace, R. J., G. A. Broderick, and M. L. Brammall. 1987. Microbial protein and peptide metabolism in rumen fluid from faunated and ciliate-free sheep. Br. J. Nutr. 58:87-93.
Wallace, R. J., and C. A. McPherson. 1987. Factors affecting the rate of breakdown of bacterial protein in rumen fluid. Br. J. Nutr. $58: 313-323$.

Williams, A. G., and G. S. Coleman. 1985. Hemicellulose-degrading enzymes in rumen ciliate protozoa. Curr. Microbiol. 12:85-90.

Williams, A. G., and G. S. Coleman. 1992. The Rumen Protozoa. Springer-Verlag, New York, NY. 